Portland State University

PDXScholar

$2-1-2004$

\title{
The Biodiversity and Biogeochemistry of Cryoconite Holes from McMurdo Dry Valley Glaciers, Antarctica
}

Dorota L. Porazinska

Andrew G. Fountain

Portland State University, andrew@pdx.edu

Thomas H. Nylen

Martyn Tranter

Ross A. Virginia

See next page for additional authors

Follow this and additional works at: https://pdxscholar.library.pdx.edu/geog_fac

Part of the Environmental Sciences Commons

Let us know how access to this document benefits you.

\section{Citation Details}

The Biodiversity and Biogeochemistry of Cryoconite Holes from McMurdo Dry Valley Glaciers, Antarctica, D. L. Porazinska, A. G. Fountain, T. H. Nylen, M. Tranter, R. A. Virginia, D. H. Wall. Arctic, Antarctic, and Alpine Research, Vol. 36, No. 1 (Feb., 2004), pp. 84-91.

This Article is brought to you for free and open access. It has been accepted for inclusion in Geography Faculty Publications and Presentations by an authorized administrator of PDXScholar. Please contact us if we can make this document more accessible: pdxscholar@pdx.edu. 
Authors

Dorota L. Porazinska, Andrew G. Fountain, Thomas H. Nylen, Martyn Tranter, Ross A. Virginia, and Diana H. Wall 


\section{The Biodiversity and Biogeochemistry of Cryoconite Holes from McMurdo Dry Valley Glaciers, Antarctica}

D. L. Porazinska,

A. G. Fountain, $\dagger$

T. H. Nylen, $\dagger$

M. Tranter $\ddagger$

R. A. Virginia, $\S$ and

D. H. Wall*

*Natural Resource Ecology Laboratory, Colorado State University, Fort Collins, CO 80523-1499, U.S.A. Current address for D. L. Porazinska: Fort Lauderdale Research and Education Center, University of Florida, FL 33314, U.S.A.

dorotac@bellsouth.net

†Departments of Geography and Geology, Portland State University, Portland, OR 97207-0751, U.S.A.

$\ddagger$ Bristol Glaciology Center, School of Geographical Sciences, University of Bristol, Bristol BS8 1SS, U.K.

$\S$ Environmental Studies Program, Dartmouth College, Hanover, NH 03755, U.S.A.

\begin{abstract}
Once thought of as inert, ice has been increasingly recognized as a habitat suitable for life. The landscape of the MCMurdo Dry Valleys (MCM) of Antarctica is dominated by glaciers, and glacier melt is the primary water source for life in soils, streams, and lakes. The glaciers, despite their cold and lifeless appearance, offer functioning habitats for life. The major objective of this study was to examine biogeochemical characteristics of miniecosystems present in cryoconite holes and to determine links to other components (soils, streams, and lakes) of the dry valley landscape. We examined cryoconite holes from 5 glaciers spanning the length of Taylor Valley, one of many valleys in the MCM. Cryoconite biotic communities were composed of the same species observed in streams and lakes, namely, cyanobacteria (Chlorococcus, Chroococcus, Crinalium, Oscillatoria, Nostoc, and Sprirulina), rotifers (Philodina gregaria and Cephalodella catellina), tardigrades (Acutuncus antarcticus and Hypsibius spp.), and ciliates. Biotic communities did not reflect the composition of the immediately surrounding environments, suggesting the effects of eolian mixing and transport of sediments and biota across the valley. Gradients of chemistry and biotic abundance in cryoconite holes reflected the position of each glacier in the valley. Nitrogen and organic carbon concentration patterns across glaciers potentially resulted from biological activities in cryoconite holes. Properties of holes were stable from one to the next sampling season, suggesting that changes of cryoconite hole properties develop on longer than yearly time scales.
\end{abstract}

\section{Introduction}

The McMurdo Dry Valleys (MCM) of Antarctica are the driest and coldest deserts on Earth (Clow et al., 1988). Mean annual temperatures range between -16 and $-21^{\circ} \mathrm{C}$, and annual precipitation (snow) does not exceed $10 \mathrm{~cm}$ water equivalent (Bromley, 1985; Doran et al., 2002a). The landscape of the MCM is dominated by bare soils, perennially frozen lakes, ephemeral streams, and glaciers. Despite the harshness of the environment, microflora and microfauna persist in soils (Freckman and Virginia, 1998; Powers et al., 1998; Courtright et al., 2001; Porazinska et al., 2002), lakes (Priscu et al., 1999), and streams (Alger et al., 1997; McKnight et al., 1999). Soil, stream, and lake food webs are limited to photosynthesizing cyanobacteria and algae, bacterial, and invertebrate assemblages. The MCM glaciers are key water sources for life in soils, streams, and lakes because of the extremely low precipitation (Fountain et al., 1999). The glaciers also provide functioning habitats for life.

Once thought of as inert, ice has been increasingly recognized as a habitat suitable for life. Melt pools on the surface of ice shelves show a diversity of life that includes cyanobacteria, heterotrophic bacteria, nematodes, protozoans, rotifers, tardigrades, and viruses (Vincent et al., 2000). The permanent ice cover on lakes also supports viable microbial life. For instance, high concentrations of bacteria occur in the accretion ice of Lake Bonney in Taylor Valley of the MCM (Priscu et al., 1998).

Dark-colored material on the glacier surface, called cryoconite (Nordenskjöld, 1875), creates melt holes that contain abundant algal and bacterial communities, but cyanobacteria, insects, rotifers, and tardigrades may also be present (e.g., Koshima, 1989; Ling and Seppelt, 1993; de Smet and van Rompu, 1994; Grongaard et al., 1999; Takeuchi et al., 2000; Takeuchi et al., 2001a, 2001b). In the MCM, Wharton
(1985) and Mueller et al. (2001) reported the presence of similar biota in cryoconite holes found beneath the ice surface of Canada Glacier.

Cryoconite holes form when soil/sediment particles absorb more solar radiation than the surrounding ice and melt into the ice, forming water-filled cylindrical holes with a sediment layer at the bottom (McIntyre, 1984). These holes are found in the ice-exposed "ablation" zone on the lower part of glaciers but not in the snow-covered "accumulation" zone on the upper part (Fig. 1). On temperate glaciers, these holes are typically open to the atmosphere during the summer ablation season and exchange water from the surrounding melt surfaces and gases with the atmosphere. In contrast, the cryoconite holes of the MCM are covered with an ice lid up to $30 \mathrm{~cm}$ thick. This lid isolates the hole from the atmosphere and the surrounding surface. Variations in air temperature and solar radiation define the size and growth rate of cryoconite holes (McIntyre, 1984). Sublimation of the ice surface may result in changes of the hole depth. In the MCM, snow cover, ice temperature, and surface roughness play a role as well.

In warm austral summers, cryoconite holes may periodically open, allowing input of inorganic and organic particles, and possibly biota, carried by the wind and meltwater. The sediment and biota accumulating in holes lowers albedo and thus may increase the rate of ice melting. Takeuchi et al. (2001b) suggested that reduced albedo of the cryoconite (due to biological activity) affects the mass balance of the glaciers by increasing melt. In the MCM, this would signify increased delivery of water to streams and perennially ice-covered lakes.

Taylor Valley, the site of the MCM Long-Term Ecological Research (LTER) project, is approximately $34 \mathrm{~km}$ long and $12 \mathrm{~km}$ wide. About one-third of the valley is covered by glaciers, which supply the water to the ephemeral streams and perennially ice-covered lakes (Fountain et al., 1999). Three lake basins (Fryxell, Hoare, and Bonney) 


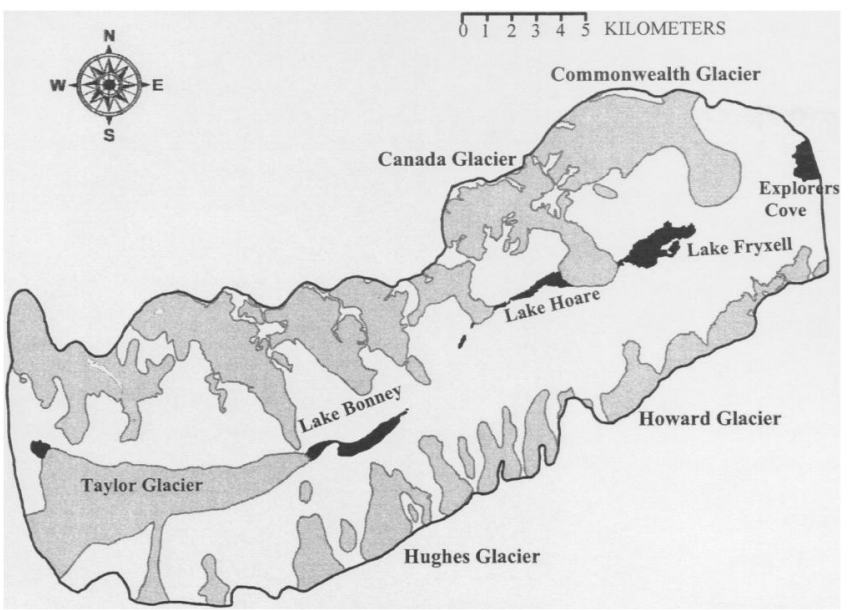

FIGURE 1. Map of locations of sampled glaciers within Taylor Valley.

divide the valley into three distinct watersheds, each supplied with water from glaciers that flow from the surrounding mountains (the Asgard Range to the north and the Kukri Hills to the south) and from a tongue of the East Antarctic Ice Sheet, Taylor Glacier (Fig. 2). The eastern part of the valley is open to McMurdo Sound, and the western part is blocked by Taylor Glacier (Fig. 2). Coastal breezes dominate the wind pattern in the summer, averaging $4 \mathrm{~m} \mathrm{~s}^{-1}$ (Doran et al., 2002a) due to the differential heating between the valley and the ice-covered ocean. Katabatic winds draining from the East Antarctic Ice Sheet affect the climate of the valleys primarily in the nonsummer months but can have a significant impact in the summer when they do occur. Katabatic winds can reach speeds of $40 \mathrm{~m} \mathrm{~s}^{-1}$ and increase local air temperatures in winter by $20^{\circ} \mathrm{C}$, due to the adiabatic heating, and reduce humidity by $20 \%$ (Nylen et al., in press). They control the spatial distribution of average seasonal and annual air temperatures (Doran et al., 2002b; Nylen et al., in press). In addition, these winds are the principal agent for transporting sediment and biologic material across the valley (Nylen et al., in press) and may be the main factor in integrating the biogeochemical functioning of soils, lakes, streams, and glaciers (Moorhead et al., 1999). We expect material transport to follow the prevalent west-to- east direction of the katabatic winds.

A strong gradient in snow precipitation exists in the valley (less than $10 \mathrm{~cm} \mathrm{yr}^{-1}$ ), decreasing inland (Fountain et al., 1999). The 700-mtall Nussmaum Riegel in the center of Taylor Valley partially blocks moisture-bearing storms from reaching the Lake Bonney basin. Thus, the Fryxell and Hoare basins on the east side of the hill receive more moisture than the Lake Bonney basin on the west side.

Previous work in the MCM LTER indicates that soil and sediment particles (Lyons et al., 2003), as well as microorganisms and nematodes (unpublished data, Wall), disperse by wind, suggesting soils, streams, and lakes as sources of inorganic particles and microbiota to the glaciers. Diversity and density of biota (particularly microinvertebrates) in Taylor Valley soils show a distinct gradient of increasing diversity and abundance from the Bonney basin (to the west) to McMurdo Sound (to the east) (Virginia and Wall, 1999). This gradient is consistent with the pattern of katabatic winds and precipitation. A similar gradient is observed for soil organic matter, while gradients in salinity and $\mathrm{pH}$ are reversed (Virginia and Wall, 1999), again consistent with katabatics.

The major objectives of this study were to define the biological characteristics of cryoconite holes and to determine which chemical and physical properties of holes define these habitats as suitable for life. In addition, we attempted to determine whether the biogeochemisty of cryoconite holes is linked to biogeochemical patterns of soils, streams, and lakes. Based on gradients in wind direction, diversity and density of

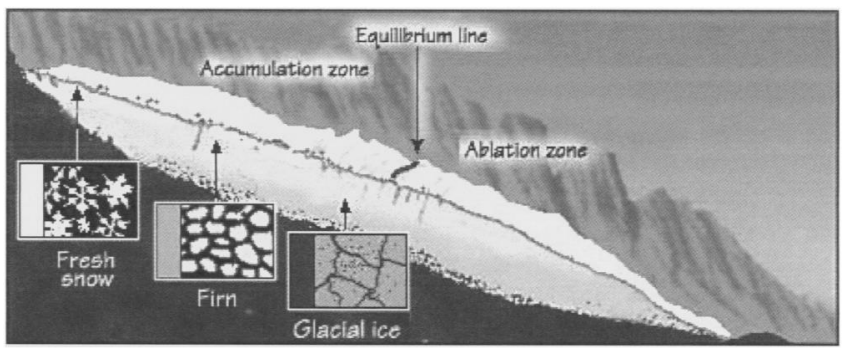

FIGURE 2. Schematic illustration of glacial zones (courtesy of F.D. Granshaw).

organisms, and the chemical characteristics of the surrounding glacier environments, we hypothesized that:

1. Microbiota species found in the lakes, streams, and soils will also be found in cryoconite holes.

2. The predominant westerly winds will result in biogeochemical differences in cryoconite holes on western vs. eastern glaciers.

3. Elevation and geographical orientation will result in biogeochemical differentiation between cryoconoite holes.

\section{Materials and Methods}

Cryoconite holes on 5 glaciers in Taylor Valley, Antarctica, were examined for morphological, chemical, and biological properties. Cryoconite holes were studied in two consecutive austral summer seasons. Canada Glacier was sampled in January 2001, and in November 2001 sampling was extended to 5 glaciers, from east to west: Commonwealth, Canada, Howard, Hughes, and Taylor (Fig. 2). All cryoconite holes sampled were entirely frozen. Holes were sampled using a SIPRE ice corer, which provides a continuous core $10 \mathrm{~cm}$ in diameter and up to $1 \mathrm{~m}$ long. One ice core per cryoconite hole (regardless of the cryoconite hole size) was excavated; the ice cores were then placed in plastic bags, transported to the laboratory at the U.S. McMurdo Station, and kept frozen $\left(-20^{\circ} \mathrm{C}\right)$ until processing. Each cryoconite hole was measured for diameter and depth (from the ice surface to the bottom of the sediment layer). In January 2002, the MCM experienced above-normal temperatures and extensive ice melting, causing the holes to open up for several days (holes are typically closed up). We resampled open holes on Canada Glacier. Water samples ( $\sim 100$ $\mathrm{mL}$ ) with sediment were removed from cryoconite holes using prewashed plastic scoops and placed in 200-mL Nalgene bottles prerinsed with deionized water. These samples were also transported to the laboratory and immediately processed for biota. Several "grab" samples from surficial sediments were collected from Canada and Taylor glaciers.

Each glacier (except Taylor) was sampled at 4 locations to measure mass change: lower west, lower east, upper west, and upper east ("upper" and "lower" refer to elevation on the glacier). Because geographical and elevational orientation of the Taylor Glacier flows from west to east, cryoconite holes were sampled on a longitudinal profile. Cryoconite hole sampling was stratified by hole size. At each location the 2 large, 2 medium, and 2 small holes were sampled. In addition, all cryoconite holes within half of the circle (2.5-m radius) were counted to estimate hole density per surface area.

In the lab, ice cores were sectioned into 6-cm slices with a saw under a laminar fume hood. This $6-\mathrm{cm}$ section provided about $300 \mathrm{~mL}$ of water. The surface of the fume hood and the saw were sterilized between samples with a $95 \%$ alcohol solution to prevent cross-contamination. Each ice core was handled with a new pair of sterilized gloves. The sections containing the sediment layer were placed in covered polyethylene specimen cups $(32 \mathrm{oz})$ previously rinsed with deionized 


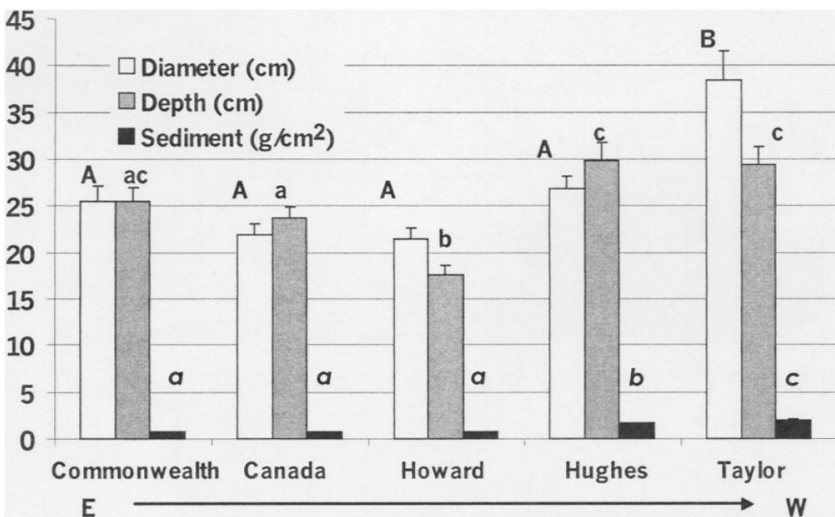

FIGURE 3. Diameter $(\mathrm{cm})$, depth $(\mathrm{cm})$, and sediment mass $\left(\mathrm{g} / \mathrm{cm}^{2}\right)$ (mean \pm standard error) of cryoconite holes of Commonwealth (Common), Canada, Howard, Hughes, and Taylor glaciers. Different letters indicate significant differences at $\mathrm{P} \leq 0.05$. Capital letters relate to differences in diameter, lowercase letters to differences in depth, and italic letters to differences in sediment mass.

water and left to melt in the lab overnight. Melted water samples were filtered for invertebrates using a standard extraction protocol (Freckman and Virginia, 1993, 1997). The remaining water was transferred into another polyethylene cup and processed immediately for major ions and dissolved organic carbon (DOC) using procedures described by Welch et al. (1996). Sediment from the filtration was placed in an oven, dried for $48 \mathrm{hr}$ at $105^{\circ} \mathrm{C}$, and weighed. Invertebrates were identified and counted within $24 \mathrm{hr}$ of extraction and then preserved in $5 \%$ formalin. Cyanobacteria and protozoa were also identified but not counted.

ANOVA analysis was used (StatView ${ }^{\circledR}$ Abacus Concept Inc.) to examine differences in the biological, chemical, and physical properties of cryoconite holes among glaciers, between elevations (low vs. high), and between sides of glaciers (east vs. west). If appropriate, the post hoc Sheffe's test was used to separate the means. Correlation analysis was used to reveal relationships among biological variables and their environment. Biological variables were also analyzed by multiple linear regression analysis (StatView ${ }^{\circledR}$ Abacus Concept Inc.) against physical and chemical parameters of cryoconite holes. Differences, coefficients of correlation, and regression were considered significant at $P \leq 0.05$. Rotifer and tardigrade abundance were $\log (\mathrm{x}+1)$ transformed prior to statistical analyses, but true numbers are presented in graphs and tables. Because frozen and melted holes are not directly comparable, the generated data sets were analyzed separately.

\section{Results}

\section{SPATIAL DIFFERENCES AMONG GLACIERS}

Taylor and Hughes glaciers had generally larger $\left(\mathrm{F}_{4,137}=10.13\right.$, $P<0.0001)$ and deeper $\left(\mathrm{F}_{4,137}=9.66, P<0.0001\right)$ holes with more sediment per $\mathrm{cm}^{2}\left(\mathrm{~F}_{4,137}=36.70, P<0.0001\right)$ than other glaciers (Fig. $3)$. Holes on Howard Glacier were significantly shallower than holes on other glaciers $\left(\mathrm{F}_{4,137}=9.66, P<0.0001\right)$. Although the average density of holes per unit area declined from $60 \mathrm{~m}^{-2}$ in the eastern part of the valley to $22 \mathrm{~m}^{-2}$ in the west, no statistically significant differences among glaciers were observed $\left(\mathrm{F}_{4,18}=1.477, P=0.2506\right)$.

Biotic communities of cryoconite holes were generally very abundant and relatively complex. We observed bacterial, cyanobacterial, and algal cells; diatoms; protozoans (particularly ciliates); rotifers; and tardigrades. In contrast to previous anecdotal reports, nematodes were not found in any cryoconite holes. However, they were observed (Plectus antarcticus) in sediment located in a surficial stream of Canada Glacier. Identified cyanobacteria included Chlorococcus, Chroococcus,
TABLE 1

Taxonomic biotic composition of cryoconite holes on glaciers in Taylor Valley, Antarctica

\begin{tabular}{|c|c|c|c|c|c|}
\hline Organism & Commonwealth & Canada & Howard & Hughes & Taylor \\
\hline \multicolumn{6}{|l|}{ Cyanobacteria } \\
\hline Chlorococcus & - & $+(\mathrm{LW})$ & - & - & $+(\mathrm{CM})$ \\
\hline Chroococcus & $+(W)$ & $+(\mathrm{LW})$ & $+(\mathrm{NA})$ & - & - \\
\hline Crinalium spp. & $+(-\mathrm{UW})$ & $+(\mathrm{L})$ & $+(\mathrm{NA})$ & - & $+(-\mathrm{T})$ \\
\hline Crinalium helicoides & $+(\mathrm{L})$ & $+(\mathrm{LW})$ & - & - & $+(-\mathrm{T})$ \\
\hline Oscillatoria limosa? & + & + & + & + & + \\
\hline Sprirulina & + & $+(\mathrm{LW})$ & $+(\mathrm{W})$ & - & $+(-\mathrm{T})$ \\
\hline Coenobium & - & - & - & + & + \\
\hline \multicolumn{6}{|l|}{ Protozoa } \\
\hline Ciliates & $+(\mathrm{NA})$ & + & + & - & + \\
\hline \multicolumn{6}{|l|}{ Invertebrates } \\
\hline Rotifers & + & + & + & - & + \\
\hline Tardigrades & + & $+(\mathrm{L})$ & + & - & + \\
\hline
\end{tabular}

$-=$ absent $+=$ present; $($ ) relates to location on a glacier; $\mathrm{CM}=$ margins at central part; $\mathrm{L}=$ lower parts of a glacier; $\mathrm{LW}=$ lower west; $\mathrm{NA}=$ present at all locations but not all holes within a location; $T=$ terminus; $U W=$ upper west; $W=$ west.

Crinalium, Oscillatoria, Nostoc, and Sprirulina. Cyanobacterial cells ?1 were present in all cryoconite holes, but their taxonomic composition varied among glaciers (Table 1). Oscillatoria was the only genus found in all holes of all glaciers. Cryoconite holes of Hughes Glacier were characterized by the presence of only Oscillatoria and Coenobium. Ciliates were found on all but Hughes Glacier.

The abundance of rotifers (Philodina gregaria the dominant species and most probably Cephalodella catellina) per $100 \mathrm{~g}$ dry sediment was significantly higher on Commonwealth and Howard glaciers $\left(\mathrm{F}_{4,136}=84.57, P<0.0001\right)$ than on Canada and Taylor glaciers (Fig. 4). Rotifers were virtually absent from holes on Hughes Glacier. The highest populations of tardigrades (Acutuncus antarcticus and Hypsibius spp.) were observed on Commonwealth Glacier $\left(\mathrm{F}_{4,136}=\right.$ 28.80, $P<0.0001$ ), but their densities were comparable among Canada, Howard, and Taylor Glaciers (Fig. 4). Cryoconite holes from Hughes Glacier were devoid of tardigrades.Concentrations of DOC were highest in cryoconite holes of Canada and Howard glaciers and lowest on the Hughes Glacier $\left(\mathrm{F}_{4,133}=8.307, P<0.0001\right)$ (Fig. 5). Concentrations of $\mathrm{NH}_{4}{ }^{+}-\mathrm{N}$ and $\mathrm{NO}_{3}{ }^{-}-\mathrm{N}$ also varied among glaciers. The dominant form

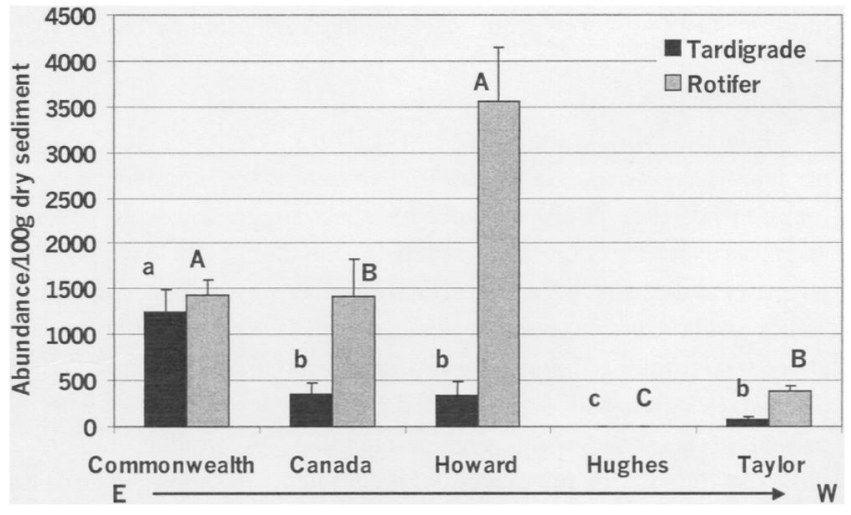

FIGURE 4. Abundance of invertebrates (\# $100 \mathrm{~g}^{-1}$ dry sediment) (mean \pm standard error) in cryoconite holes of Commonwealth $(N=$ $24)$, Canada $(N=24)$, Howard $(N=24)$, Hughes $(N=24)$, and Taylor $(N=38)$ glaciers. Black bars indicate tardigrades and checked bars rotifers. Capital letters indicate significant differences at $\mathrm{P} \leq 0.05$ among glaciers for rotifers, and lowercase letters indicate significant differences at $\mathrm{P} \leq 0.05$ among glaciers for tardigrades. 


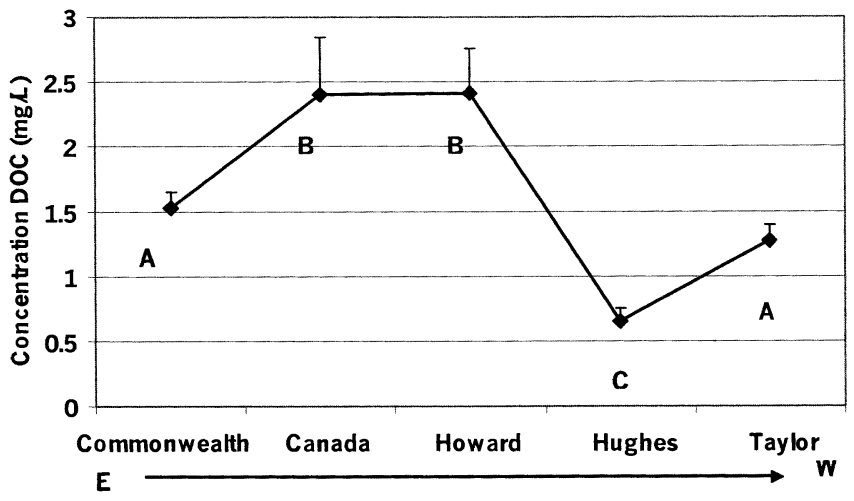

FIGURE 5. Concentrations of dissolved organic carbon (DOC) (mean \pm standard error) in cryoconite holes of Commonwealth $(N=$ $24)$, Canada $(N=24)$, Howard $(N=24)$, Hughes $(N=24)$, and Taylor $(N=38)$ glaciers. Letters indicate significant differences at $\mathrm{P} \leq 0.05$.

of dissolved inorganic nitrogen in cryoconite holes on Canada and Howard glaciers was $\mathrm{NH}_{4}{ }^{+}-\mathrm{N}$, while on Commonwealth, Hughes, and Taylor glaciers it was $\mathrm{NO}_{3}{ }^{-}-\mathrm{N}$ (Fig. 6). Canada Glacier had holes with significantly higher concentrations of $\mathrm{NH}_{4}{ }^{+}-\mathrm{N}$ than other glaciers. Holes from Hughes Glacier had the highest concentrations of $\mathrm{NO}_{3}{ }^{-}-\mathrm{N}$ ( $\sim 4$ times higher), while holes from Howard Glacier had the lowest.

Generally, concentrations of cations $\left(\mathrm{Na}^{+}, \mathrm{K}^{+}, \mathrm{Ca}^{2+}\right.$, and $\left.\mathrm{Mg}^{2+}\right)$ and anions $\left(\mathrm{Cl}^{-}, \mathrm{SO}_{4}{ }^{2-}\right)$ were highest in cryoconite holes from Commonwealth Glacier and lowest in holes from Taylor Glacier (Fig. 7). Values of $\mathrm{pH}$ were inverse to the concentrations of $\mathrm{NO}_{3}{ }^{-}-\mathrm{N}$. The lowest $\mathrm{pH}$ values were in cryoconite holes from Hughes Glacier, followed by Taylor, Commonwealth, and Canada, and the highest at Howard Glacier $\left(\mathrm{F}_{4,135}=92.480, P<0.0001\right)$ (Fig. 8).

\section{DIFFERENCES BETWEEN ELEVATIONS AND SIDES}

Data from Commonwealth, Canada, Howard, and Hughes glaciers were used to determine differences between low and high elevations and east and west sides of glaciers because these have a similar north-south orientation. Taylor Glacier was excluded because of the glacier's eastwest orientation. Overall, there were no differences between lower vs. upper parts of glaciers in the size of cryoconite holes (depth $=24.0 \mathrm{~cm}$, standard error $(\mathrm{SE})=0.9$; diameter $=23.8 \mathrm{~cm}, \mathrm{SE}=0.7)$ or in sediment concentration (mean $=0.92 \mathrm{~g} / \mathrm{cm}^{2}, \mathrm{SE}=0.06$ ). No differences in those

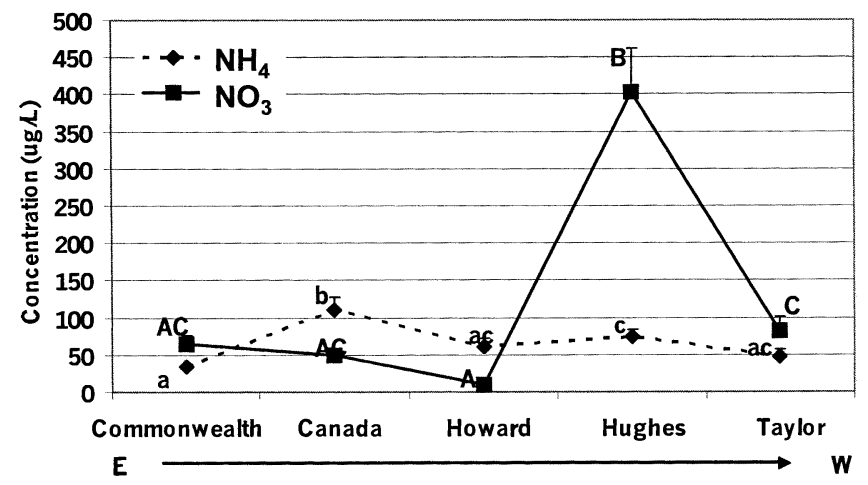

FIGURE 6. Concentrations of ammonium $\left(\mathrm{NH}_{4}^{+}\right)$and nitrate $\left(\mathrm{NO}_{3}{ }^{-}\right)$ (mean \pm standard error) in cryoconite holes of Commonwealth $(N=$ $24)$, Canada $(N=24)$, Howard $(N=24)$, Hughes $(N=24)$, and Taylor $(N=38)$ glaciers. Dashed lines show ammonium levels and continuous lines show nitrate levels. Capital letters indicate significant differences at $\mathrm{P} \leq 0.05$ among glaciers for nitrate, and lowercase letters indicate significant differences at $\mathrm{P} \leq 0.05$ among glaciers for ammonium.
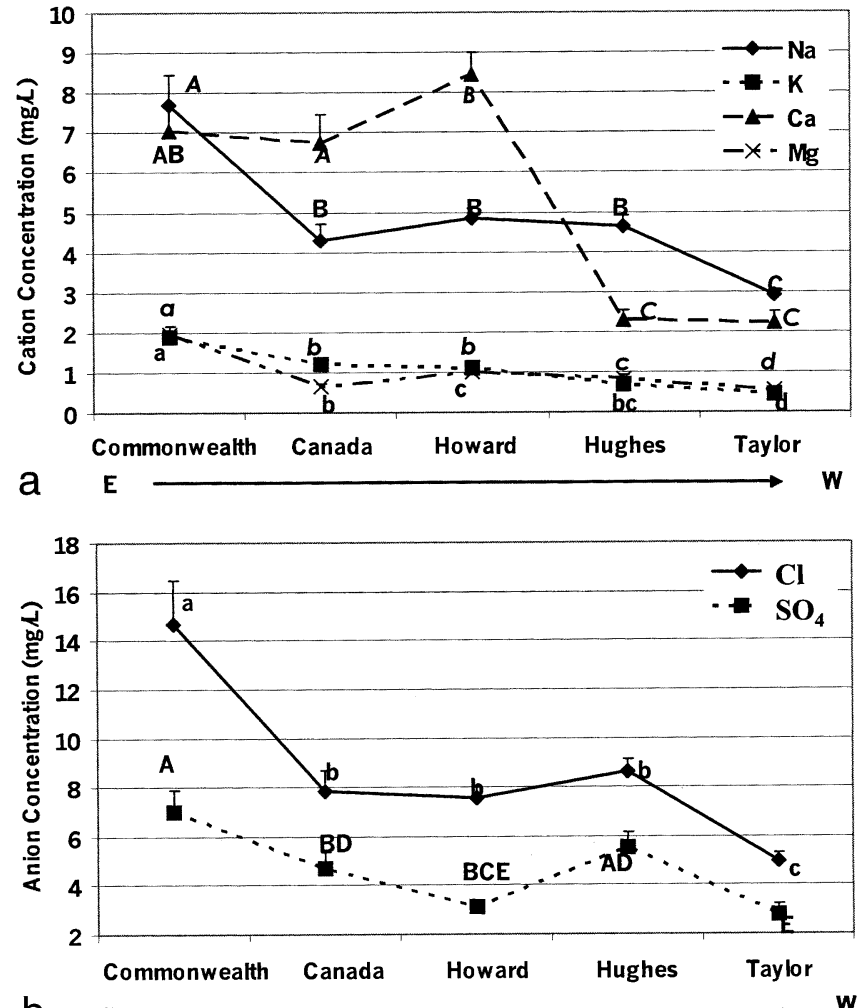

b $\mathbf{E}$

FIGURE 7. Concentrations of (a) cations: sodium $\left(\mathrm{Na}^{+}\right.$, continuous line), calcium $\left(\mathrm{Ca}^{+2}\right.$, dashed with triangles line $)$, potassium $\left(\mathrm{K}^{+}\right.$, dashed with squares line), and magnesium $\left(\mathrm{Mg}^{+2}\right.$, dashed with crisscross line) and (b) anions: chloride ( $\mathrm{Cl}$, continuous line) and sulfate $\left(\mathrm{SO}_{4}{ }^{-2}\right.$, dashed line) (mean \pm standard error) in cryoconite holes of Commonwealth $(N=24)$, Canada $(N=24)$, Howard $(N=24)$, Hughes $(N=24)$, and Taylor $(N=38)$ glaciers. Capital letters indicate significant differences at $\mathrm{P} \leq 0.05$ among glaciers for $\mathrm{Na}^{+}$and $\mathrm{SO}_{4}{ }^{-2}$, italic capital letters indicate significant differences at $\mathrm{P} \leq 0.05$ among glaciers for $\mathrm{Ca}$, lowercase letters indicate significant differences at $\mathrm{P} \leq 0.05$ among glaciers for $\mathrm{K}$, and $\mathrm{Cl}$, and italic lowercase letters indicate significant differences at $\mathrm{P} \leq 0.05$ among glaciers for $\mathrm{Mg}$.

parameters were observed between east and west sides of glaciers. In contrast to physical characteristics, biological properties were somewhat affected by location on the glacier. Cyanobacteria were often present only at the lower and western sides of glaciers (particularly on

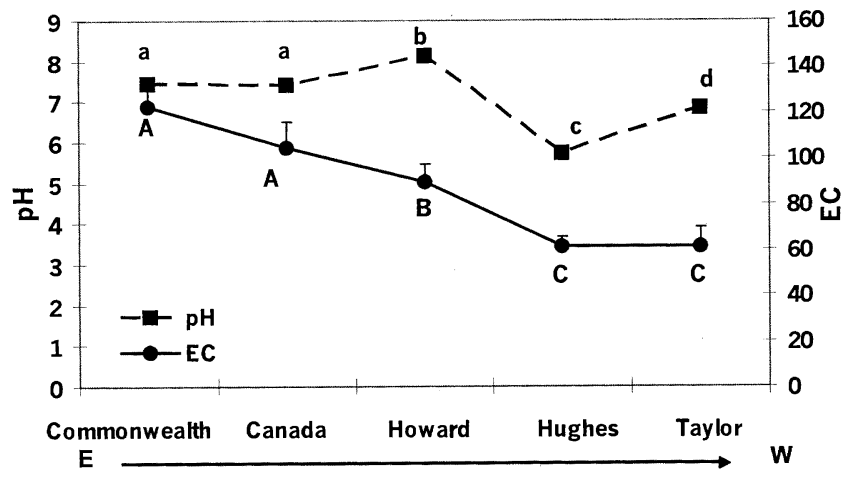

FIGURE 8. Acidity ( $p H$, dashed line) and salinity (EC, continuous line) (mean \pm standard error) in cryoconite holes of Commonwealth $(N=24)$, Canada $(N=24)$, Howard $(N=24)$, Hughes $(N=24)$, and Taylor $(N=38)$ glaciers. Capital letters indicate significant differences at $\mathrm{P} \leq 0.05$ among glaciers for salinity, and lowercase letters indicate significant differences at $\mathrm{P} \leq 0.05$ among glaciers for $\mathrm{pH}$. 
Relationship between invertebrate abundance and properties of cryoconite holes as the best-fitted multiple regression model

\begin{tabular}{|c|c|c|}
\hline Equation & $R^{2}$ & $P$ \\
\hline \multicolumn{3}{|l|}{ All Glaciers } \\
\hline $\begin{aligned} \text { Rotifer }^{\mathrm{a}}= & -1.78+0.48 \mathrm{pH}-0.005 \mathrm{NH}_{4}^{+} \\
& -0.003 \mathrm{NO}_{3}{ }^{-}+0.12 \mathrm{Ca}^{2+}+0.02 \text { Diam }\end{aligned}$ & 0.62 & $<0.0001$ \\
\hline $\begin{aligned} \text { Tardigrade }= & 1.33-0.005 \mathrm{NH}_{4}^{+}-0.003 \mathrm{NO}_{3}^{-} \\
& +0.78 \mathrm{Mg}^{2+}\end{aligned}$ & 0.41 & $<0.0001$ \\
\hline \multicolumn{3}{|l|}{ Canada Glacier } \\
\hline Rotifer $=1.47+0.015 \mathrm{Sed}$ & 0.15 & $=0.0072$ \\
\hline $\begin{aligned} \text { Tardigrade }= & 0.16+0.056 \mathrm{Diam}+0.015 \mathrm{Sed}- \\
& 0.231 \mathrm{Na}^{+}\end{aligned}$ & .38 & $=0.0002$ \\
\hline
\end{tabular}

${ }^{\text {a }}$ Rotifer and tardigrade abundance was $\log$ transformed. $R^{2}$ indicates proportion of variance explained. $P$ indicates statistical significance of the relationship. Sed $=$ sediment mass; Diam $=$ diameter.

Commonwealth, Canada, and Howard). Although no differences were found for rotifers (mean $=1630$ individuals $100 \mathrm{~g}^{-1}$ dry sediment, $\mathrm{SE}=$ $230)$, tardigrades were more numerous at lower $($ mean $=530, \mathrm{SE}=120)$ than upper elevations (mean $=460, \mathrm{SE}=150)\left(\mathrm{F}_{1,92}=10.90, P=\right.$ 0.0014 ). Generally, no differences in the chemistry were observed except for sodium concentration, which was greater at upper elevations $\left(F_{1,93}=9.020, P=0.0 .0034\right)$. Also, concentrations of $\mathrm{K}^{+}$were higher $\left(F_{1,93}=3.978, P=0.049\right)$ and concentrations of $\mathrm{NO}_{3}{ }^{-}$were lower $\left(\mathrm{F}_{1,72}=4.5, P=0.0373\right)$ on the east side of the glaciers.

\section{RELATIONSHIPS}

Rotifer and tardigrade abundances were positively correlated with each other $(r=0.70, P<0.0001)$. Deeper holes with more sediment had significantly fewer rotifers $(r=-0.21, P \leq 0.05)$ and tardigrades $(r=-$ $0.20, P \leq 0.05$ ). Holes with higher densities of both invertebrates had significantly higher $\mathrm{pH}$ and DOC (average $r=0.34, P \leq 0.05$ ) and lower $\mathrm{NO}_{3}{ }^{-}$concentrations (average $r=-0.50, P<0.0001$ ). Both rotifers and tardigrades were positively correlated with concentrations of $\mathrm{K}$ (average $r=0.31, P \leq 0.0005$ ), $\mathrm{Mg}$ (average $r=0.26, P \leq 0.003$ ), and $\mathrm{Ca}$ (average $r=0.38, P \leq 0.001$ ). However, multiple regression always suggests that rotifer variation was best explained by $\mathrm{pH}, \mathrm{NH}_{4}^{+}, \mathrm{NO}_{3}{ }^{-}$, $\mathrm{Ca}^{2+}$, and hole diameter, while tardigrade variation was best explained by $\mathrm{NH}_{4}{ }^{+}, \mathrm{NO}_{3}{ }^{-}$, and $\mathrm{Mg}^{2+}$ (Table 2 ).

\section{CANADA GLACIER}

Collection of data over a period of a year allowed us to examine cryoconite holes in more detail and examine any differences with time. Cryoconite holes were deeper during January 2001 than in November $2001\left(\mathrm{~F}_{1,45}=58.79, P<0.0001\right)$, but no differences in hole diameter, sediment mass, and invertebrate numbers were found (Table 3). Overall, holes at the lower elevation were significantly larger $\left(\mathrm{F}_{1,45}=21.07\right.$, $P<0.0001)$ and had more sediment $\left(\mathrm{F}_{1,45}=8.59, P=0.0054\right)$, rotifers $\left(\mathrm{F}_{1,45}=38.33, P<0.0001\right)$, and tardigrades $\left(\mathrm{F}_{1,45}=98.33, P<0.0001\right)$ than holes at higher elevations. No differences in the properties of cryoconite holes between eastern and western sides were observed. Samples recovered from melted and frozen holes had identical biological composition.

\section{RELATIONSHIPS ON CANADA GLACIER}

Rotifer and tardigrade abundances were positively correlated ( $r=$ $0.62, P<0.0001)$. An increase of cryoconite hole diameter and amount of sediment was associated with an increase of rotifers and tardigrades (average $r=0.37, P<0.05$ ). Tardigrades were negatively associated
Morphological and invertebrate differences between sampling seasons, elevations, and sides on Canada Glacier. Data represent averages

\begin{tabular}{|c|c|c|c|c|c|c|}
\hline \multirow[b]{2}{*}{ Variable } & \multicolumn{2}{|c|}{ Sampling season } & \multicolumn{2}{|c|}{ Elevation } & \multicolumn{2}{|c|}{ Side } \\
\hline & Jan. 2001 & Nov. 2001 & Low & High & West & East \\
\hline Diameter (cm) & 22.0 & 21.9 & 26.2 & $17.1^{\mathrm{a}}$ & 22.0 & 21.9 \\
\hline Depth (cm) & 36.8 & $23.8^{\mathrm{a}}$ & 32.2 & $27.8^{\mathrm{a}}$ & 28.2 & 31.8 \\
\hline Sediment $\left(\mathrm{g} / \mathrm{cm}^{2}\right)$ & 53.4 & 57.6 & 68.1 & $41.3^{\mathrm{a}}$ & 56.2 & 55.1 \\
\hline Rotifers (\#/100 g ds) & 2070 & 1414 & 2908 & $402^{\mathrm{a}}$ & 2924 & 774 \\
\hline Tardigrades $(\# / 100 \mathrm{~g} \mathrm{ds})$ & 4636 & 351 & 4442 & $182^{\mathrm{a}}$ & 844 & 3743 \\
\hline
\end{tabular}

a indicates statistical significance at $P<0.05$; ds $=$ dry sediment.

with higher concentrations of $\mathrm{Na}^{+}(r=-0.34, P=0.021), \mathrm{K}^{+}(r=-0.377$, $P=0.010)$, and $\mathrm{Cl}^{-}(r=-0.31, P=0.038)$. Using a multiple regression model, rotifer density was best predicted by amount of sediment and tardigrades by hole diameter, amount of sediment, and concentrations of $\mathrm{Na}^{+}$(Table 2).

\section{Discussion}

Cryoconite holes were present on all of the glaciers we examined, and as in other glaciated regions of the world (McIntyre, 1984; Takeuchi et al., 2000), cryoconite holes were generally circular to elliptical and the depth was independent of the diameter. We anticipated that density of holes would be dependent on wind and sediment sources, and thus there should be fewer holes on Taylor Glacier and more holes further downvalley. Although such a trend existed, the differences in hole density among glaciers were not statistically significant. There are several possible confounding processes. Taylor Glacier has a much larger ablation zone than the other glaciers, which may create more opportunity for sediment to become trapped over time, even though the sources of sediment may be smaller at the upper end of the valley. The katabatic winds skipping over the Kukri Hills might also be a significant source of sediment. Although we have focused on eolian transport of sediment, contributions may also come from intermittent rockfalls or avalanches.

We expected fewer holes at higher elevations on glaciers because of lower sediment input from eolian transport (Lyons et al., 2003) and shorter annual duration of exposed ice surface. Contrary to our expectations, the density and physical characteristics of holes were similar for both higher and lower elevations, indicating that sediment contributions are not (as previously mentioned) limited to eolian deposition. The lack of evidence for a clear, wind-dominated pattern (east vs. west) of cryoconite sediment implies that other, unrecognized factors play an important role in defining the frequency distribution of cryoconite holes.

The largest and deepest holes were found on glaciers in the western part of Taylor Valley. This may result from the spatial climatic pattern in Taylor Valley (Fountain et al., 1999). The Nussbaum Riegel divides Taylor Valley into two climatic regimes. To the east, toward the coast, the weather is cooler with more snowfall and less wind. To the west, inland, the climate is warmer and more windy, with less snowfall. Consequently, the cryoconite holes tend to be deeper inland due to the increased solar radiation because the ice surfaces are infrequently covered with snow. The difference in hole diameter remains unexplained.

The most biologically productive cryoconite holes were found on glaciers on the east side of Taylor Valley. We expected that microorganisms in cryoconite holes came from nearby aquatic and terrestrial sources (eolian transport) and thus that the biodiversity and productivity of holes would reflect local differences in the abundance of 
soil and sediment biota. Our results indeed reflect the large-scale productivity gradients observed in the valley (Alger et al., 1997; Virginia and Wall, 1999). Productivity of streams seemed particularly important because biotic communities of cryoconite holes more closely resembled aquatic environments than the terrestrial environments. Alger et al. (1997) reported biota from Taylor Valley streams and noted that abundance of cyanobacteria, as well as invertebrates, drastically declined from the Fryxell toward the Bonney basin. The gradient of biota abundance on glaciers might also be associated with the density of streams surrounding the glaciers. While multiple streams dissect Fryxell basin, the number of streams in Bonney basin is much lower. Thus, we expected lower productivity on Taylor Glacier than on Hughes Glacier. Higher productivity of even the westernmost and uppermost sites on Taylor Glacier than of any sites on Hughes Glacier is a surprise that implies a presence of unrecognized biotic sources for Taylor Glacier and thus warrants further investigation. We know of several lakes (e.g., Joyce) in the regions of upper Taylor Glacier, but no biological information about those lakes is available at this time. It is important to determine how far south toward the polar plateau cryoconite holes support life and what are the sources of life, organic matter, and nutrients.

In addition to observing high productivity of living organisms, we demonstrate that biota in cryoconite holes provide habitats for relatively diverse microbial communities that are organized in relatively complex food webs. We suggest that photosynthesizing cyanobacteria form the bases of these food webs, and therefore their activity is a major driver of cryoconite hole processes. For example, species richness and composition of cyanobacterial populations might reflect productivity of glaciers (species richness was lowest on Hughes Glacier). Since cryoconite holes can be sealed and thus isolated from atmospheric inputs for years, photosynthetically produced organic carbon must serve as an energy source for the remaining constituents of cryoconite hole food webs. Our and other studies of cryoconite holes show that the photosynthetically derived carbon supports a variety of microfauna, including tardigrades and rotifers (Takeuchi et al., 2000; Grongaard et al., 1999; De Smet and Van Rompu, 1994) and protozoans. Again, their abundance and diversity might be directly linked to the composition and diversity of cyanobacteria. Moreover, cryoconite holes might provide a previously unrecognized source of carbon to the valley ecosystem that becomes available during infrequent warm flushing events when cryoconite material is transported via meltwater to streams, lakes, and soils. The recycling of nutrients and decomposition and mineralization of organic material in cryoconite holes is most probably carried out by heterotrophic bacteria (Vincent et al., 2000) and fungi, although records of fungi in cryoconite holes are lacking. Preliminary measurements of the bacterial component of the cryoconite hole food web indicate significant bacterial production (Foreman, personal communication).

The composition of biotic communities varied among glaciers, although the differences applied predominantly to primary producers. Species occupying higher levels within trophic food webs were similar at all glaciers regardless of the glacier's position in the valley. The observed cyanobacterial and microinvertebrate species have been previously reported from aquatic environments in the McMurdo Sound region (Murray, 1910; Wharton et al., 1981; Alger et al., 1997), but the species composition did not directly reflect the composition of surrounding environments, indicating possible mixing of species by wind currents. Alternatively, because antarctic cryoconite holes can remain isolated from the outside environment for years (unpublished data, Fountain), they might induce development of unique biotic communities. The absence in cryoconite holes (as well as surficial sediment deposits) of the most ubiquitous invertebrate, the nematode, is easily explained. The most widespread and abundant soil nematode, Scottnema lindsayae, is known to prefer dry rather than moist environments (Powers at al., 1998; Porazinska et al., 2002). Therefore, surficial stream sediments (often saturated with water) on glaciers and aquatic cryoconite holes are probably not a suitable habitat for this species. On the other hand, Plectus antarcticus prefers wetter soil habitats and thus is present in the surficial stream sediments. Apparently, freezing in water-filled holes limits its survival. Cryptobiosis of nematodes can be induced by low temperatures through limiting water availability (anhydrobiosis), but cryobiosis might be more common among rotifers and tardigrades than nematodes (Somme, 1996). Rotifers and tardigrades in Taylor Valley are occasionally observed in soil samples but are usually associated with aquatic environments (Treonis et al., 1999) and thus might be preadapted to survive freezing in water.

Cryoconite holes are characterized by the presence of aquatic rather than soil organisms. Studies of glacial cryoconite holes from Spitsbergen, Greenland, and Nepal reported biota similar to our study with bacteria, cyanobacteria, algae, protozoans, rotifers, and tardigrades (de Smet and van Rompu, 1994; Grongaard et al., 1999; Takeuchi et al., 2000). Bdelloid rotifers and eutardigrades were common to all sites. No nematodes were found in any of these cryoconite holes.

The presence of biota in cryoconite holes can impact cryoconite hole dynamics and thus glacier albedo and mass balance. Biota and their activity have been shown to affect hole dimensions. McIntyre (1984) pointed out that biological activity generates metabolic heat that contributes to hole enlargement on glaciers in polar regions. He showed that the absence of microbial communities significantly reduced hole growth rates by killing organic constituents of the cryoconite with copper sulphate crystals. He estimated that the biological contribution to hole melting was approximately $10 \%$, and thus the generated heat was significant for melting of holes. In addition, biological processes may reduce sediment albedo due to dark-colored humic substances formed during decomposition of organic matter (dead microbial biomass, dead cyanobacterial and algal cells, gelatinous matrix, and dead microfauna) (Takeuchi et al., 2001a, 2001b). Dark-colored materials absorb solar energy more effectively and accelerate melting. The size of holes and rate of melting, therefore, should reflect in part microbial and photosynthetic biomass and activity. Biotic activity in cryoconite holes might be of significant importance to the functioning of the entire dry valley ecosystem because glacial melt is the main source of water.

The chemical gradient in sea salt and other ions along the valley results from local differences in ice chemistry, although ion concentrations in the holes were 2 to 3 orders of magnitude higher than those of the glacier ice due to scavenging effects during melting. Our results follow those of Lyons et al. (2003) for surface ice and snow on glaciers. Generally, concentrations of cations and anions in glacier ice and the cryoconite holes decrease inland due to increasing distance from the marine source of aerosols and due to a decrease in eolian-transported dust. The MCM soils contain abundant salts (e.g., $\mathrm{NaCl}$ ), so the $\mathrm{Na}$ concentration indicates both marine and terrestrial sources. The local increase in $\mathrm{Ca}$ at Howard Glacier is also consistent with Lyons et al. (2003) and reflects a local source of $\mathrm{CaCO}_{3}$.

Recent findings by Lancaster (2002) show that the dust transport on the valley floor increases with distance inland and contrasts with the particulate concentrations in snow and ice (Lyons et al., 2003). This supports the findings of Lyons et al. (2003) that dust concentration decreased with increasing elevation. The Lancaster (2002) study is not necessarily inconsistent from two perspectives. First, ice is formed at altitude on the glaciers and therefore in low-dust environments, so the initial particulate content of the pure ice should not be subject to local environmental conditions. Second, the deposition of particulates on the surface is subject to local wind speeds and surface roughness (Nylen et al., in press).

Nutrient concentrations, such as ammonium and nitrate (ions directly linked to biological processes), did not conform to gradients observed for other chemical constituents. Ammonium concentrations were elevated in the cryoconite holes of Howard and Hughes glaciers 
but were relatively similar at other glaciers. Nitrate concentrations at Hughes Glacier were an order of magnitude higher than at other glaciers. Soil environments immediately surrounding Hughes Glacier are probably the most dominant sources of sediment and $\mathrm{N}$ in cryoconite holes. The soils around Hughes Glacier are characterized by the highest levels of nitrate saturation in Taylor Valley (Courtright et al., 2001). We suspect that, in contrast to other chemical constituents, ammonium and nitrate concentrations are also partially influenced by biological activity. If we assume that the abundance of rotifers and tardigrades illustrates the abundance of primary producers in cryoconite holes, high concentrations of nitrate on Hughes Glacier could be explained by low biological uptake and thus an accumulation of nitrate.

The relatively high concentrations of ions in cryoconite holes indicate these miniecosytems are rich in total dissolved nutrients and that biological activity might in turn play an important role in the storage, recycling, and accumulation of solutes (Tranter et al.,2004). Is it possible that patterns observed for chemical constituents, $\mathrm{pH}$, and salinity result partially from biological processes? Concentrations of DOC clearly indicate the overall significance of photosynthetic and decomposition processes, as does the presence of high densities of invertebrates. Where life is most scarce (e.g., on Hughes Glacier), little organic carbon is produced and there is little nutrient depletion and assimilation. Tranter et al. (2004) observed depletion of dissolved inorganic carbon (DIC) in cryoconite holes and argued that high $\mathrm{pH}$ values result from photosynthesis. It was also suggested that high DOC formed during decomposition prevents precipitation of $\mathrm{CaCO}_{3}$ and thus further preserves DIC for photosynthesis. In other words, cryoconite holes maintain chemical balance through biological and chemical processes within the holes. For example, the lowest $\mathrm{pH}$ values were found in holes devoid of invertebrates and with low rates of production. We propose that the composition and complexity of food webs in cryoconite holes are influenced by the strength of biotic interactions with physical factors (ion inputs, climate). For instance, the variation in the dominant forms of nitrogen in cryoconite holes among glaciers probably reflects differences in the microbial composition and food-web structure creating functional differences in biochemical processes.

The similarity of the characteristics of cryoconite holes at different elevations and east and west sides of glaciers clearly implies strong effects of local wind turbulence and the presence of other than eolian transport of sediments and biota. However, on a scale of an individual glacier the local patterns can be contrary to the general trend. For instance, cryoconite holes from Canada Glacier showed differences between lower and upper elevations. Importance of scale was also illustrated by different correlation and regression coefficients between invertebrates and chemistry across glaciers (regional scale) vs. Canada Glacier (local scale). These differences suggest a strong influence of local environmental conditions.

Temporal scale is often considered an important factor in evaluating the properties of biological populations and their activity. Technically, cryoconite holes should be unaffected by the immediate, short-term effects because biological activity is limited to a few weeks within a year, if it occurs at all. The similarity of the characteristics of cryoconite holes between sampling seasons (January 2001 vs. November 2001) confirms our expectations and suggests that properties of holes are indeed relatively stable over short time scales.

\section{Condusions}

Biological species and communities of cryoconite holes resembled more closely those found in aquatic rather than terrestrial habitats. The overlapping species assemblages across glaciers suggest mixing of sediment and biota inputs by the wind on a regional scale. The gradients of biotic abundance and of the majority of chemical constituents in cryoconite holes were driven by the position of a glacier within the valley, indicating effects of small-scale environmental characteristics on the properties of cryoconite holes. Nitrogen and organic carbon patterns across glaciers seemed to be influenced by biological activity in cryoconite holes. The properties of holes were stable from one to the next sampling season, suggesting that changes of cryoconite hole properties develop only on a long (years to decades) rather than short (months to years) time scale.

\section{Acknowledgments}

We thank all who contributed to this research project, particularly W. B. Lyons, who supported initiation of the study, K. A. Welch and K. Dodgett for chemical and nutrient analyses, and R. Johnston and N. Alhadeff for assistance in the field. We thank N. DeCrappeo and S. Blacker for help in processing ice cores, extraction of invertebrates, and measuring $\mathrm{pH}$ and salinity. We thank S. J. McInnes for assistance in identification of tardigrade species. We thank the staff of the McMurdo station for logistical support in the field and laboratory, and support of the Petroleum Helicopters International. This research was supported by National Science Foundation grants OPP 9813061 and OPP 0096250.

\section{References Gited}

Alger, A. S., McKnight, D. M., Spaulding, S. A., Tate, C. M. Shupe, G. H., Welch, K. A., Edwards, R., Andrews, E. D., and House, H. R., 1997: Ecological processes in a cold desert ecosystem: the abundance and species distribution of algal mats in glacial meltwater streams in Taylor Valley, Antarctica. University of Colorado, Institute of Arctic and Alpine Research, Occasional Paper No. 51.

Bromley, A. M., 1985: Water observations, Wright Valley, Antarctica. New Zealand Meteorological Service, 11.

Clow, G. D., McKay, C. P., Simmons, Jr., G. M., and Wharton, Jr., R. A. 1988: Climatological observations and predicted sublimation rates at Lake Hoare, Antarctica. Journal of Climatology, 1: 715-728.

Courtright, E. M., Wall, D. H., and Virginia, R. A., 2001: Determining habitat suitability for soil invertebrates in an extreme environment: the McMurdo Dry Valleys, Antarctica. Antarctic Science, 13: 9-17.

De Smet, W. H., and Van Romptu, E. A., 1994: Rotifera and Tardigrada from some cryoconite holes on a Spitsbergen (Svalbard) Glacier. Belgian Journal of Zoology, 124: 27-37.

Doran, P. T., McKay, C. P., Clow, G. D., Dana, G. L., Fountain, A. G., Nylen, T., and Lyons, W. B., 2002a: Climate regime of the McMurdo Dry Valleys, Antarctica, 1986-2000. Journal of Geophysical Research-Atmospheres, 107(D24), 4772, doi: 10.1029/ 2001JD002045.

Doran P. T., Priscu, J. C. Lyons, W. B. Walsh, J. E., Fountain, A. G., McKnight, D. M., Moorhead, D. L., Virginia, R. A., Wall, D. H., Clow, G. D., Fritsen, C. H., McKay, C. P., and Parsons, A. P., 2002b: Antarctic climate cooling and terrestrial ecosystem response. Nature, 415: 517-520.

Fountain, A. G., Lyons, W. B., Burkins, M. B., Dana, G. L., Doran, P. T., Lewis, K. J., McKnight, D. M., Moorhead, D. L., Parsons, A. N., Priscu, J. C., Wall, D. H., Wharton, Jr., R. A., and Virginia, R. A., 1999: Physical controls on the Taylor Valley Ecosystem, Antarctica. BioScience, 49: 961-971.

Freckman, D. W., and Virginia, R. A., 1993: Extraction of nematodes from Dry Valley Antarctic soils. Antarctic Journal of the United States, 26, 233-234.

Freckman, D. W., and Virginia, R. A., 1997: Low-diversity antarctic soil nematode communities: distribution and response to disturbance. Ecology, 78: 363-369.

Freckman, D. W., and Virginia, R. A., 1998: Soil biodiversity and community structure in the McMurdo Dry Valleys, Antarctica. In Priscu, J. C. (ed.), Ecosystem Dynamics in a Polar Desert: The McMurdo Dry Valleys, Antarctica. Washington, DC: American Geophysical Union, 323-335.

Grongaard, A., Pugh, P. J. A., and McInnes, S. J., 1999: Tardigrades, and other cryoconite biota, on the Greenland Ice Sheet. Zoologischer Anzeiger, 238: 211-214. 
Kohshima, S., 1989: Glaciological importance of micro-organisms in the surface mud-like materials and dirt layer particles of the Chongce Ice Cap and Gozha Glacier, West Kunlun Mountain, China. Bulletin of Glacier Research, 7: 59-66.

Lancaster, N., 2002: Flux of aeolian sediment in the McMurdo Dry Valleys, Antarctica: a preliminary assessment. Arctic, Antarctic, and Alpine Research, 34: 318-323.

Ling, H. U., and Seppelt, R. D., 1993: Snow algae of the Windmill Island, continental Antarctica. 2. Chloromonas rubroleosa sp. nov. (Volvocales, Chlorophyta), an alga of red snow. European Journal of Phycology, 28: 77-84.

Lyons, W. B., Welch, K. A., Fountain, A. G., Dana, G., and Vaughn, B. H., 2003: Surface glaciochemistry of Taylor Valley, Southern Victoria Land, Antarctica and its effect on stream chemistry. Hydrologic Processes, 17: 115-130.

McIntyre, N. F., 1984: Cryoconite hole thermodynamics. Canadian Journal of Earth Science, 21: 152-156.

McKnight, D. M., Niyogi, D. K., Alger, A. S., Bomblies, A. B., Conovitz, P. A., and Tate, C. M., 1999: Dry Valley streams in Antarctica: ecosystems waiting for water. BioScience, 49: 985995.

Moorhead, D. L., Doran, P. T., Fountain, A. G., Lyons, W. B., McKnight, D. M., Priscu, J. C., Virginia, R. A., and Wall, D. H., 1999: Ecological legacies: impacts on ecosystems of the McMurdo Dry Valleys. Bioscience, 49: 1009-1019.

Mueller, D. R., Vincent, W. F., Pollard, W. H., and Fritsen, C. H., 2001: Glacial cryoconite ecosystems: a bipolar comparison of algal communities and habitats. Nova Hedwigia, 123, 171-195.

Murray, J., 1910: Antarctic Rotifera. In Murray, J. (ed.), British Antarctic Expedition, 1907 1909: Reports on the Scientific Investigations. Vol. 1, Biology. London: William Heinemann, 41-65.

Nordenskjöld, N. E., 1875: Cryoconite found 1870, July 19th-25th, on the inland ice, east of Auleitsivik Fjord, Disco Bay, Greenland. Geological Magazine, Decade 2: 157-162.

Nylen, T. H., Fountain, A. G., and Doran, P. T., in press. Climatology of katabatic winds in the McMurdo Dry Valleys, Antarctica. Journal of Geophysical Research.

$\rightarrow$ Porazinska, D. L., Wall, D. H., and Virginia, R. A., 2002: Population age structure of nematodes in the Antarctic Dry Valleys: perspectives on time, space, and habitat suitability. Arctic, Antarctic, and Alpine Research, 34: 158-169.

Powers, L. E., Ho, M., Freckman, D. W., and Virginia, R. A., 1998: Distribution, community structure, and microhabitats of soil invertebrates along an elevational gradient in Taylor Valley, Antarctica. Arctic and Alpine Research, 30: 133-141.

Priscu, J. C., Wolf, C. F., Takacs, C. D., Frietsen, C. H., LaybournPerry, J., Roberts, E. C., Sattler, B., and Lyons, W. B., 1999: Carbon transformations in a perennially ice-covered Antarctic lake. BioScience, 49: 997-1008.

Priscu, J. C., Fritsen, C. H., Adams, E. E., Giovannoni, S. J., Pearl, H. W., McKay, C. P., Doran, P. T., Gordon, D. A., Lanoil, B. D., and Pinckney, J. L., 1998: Perennial Antarctic Lake ice: an oasis for life in a polar desert. Science, 280: 2095-2098.

Somme, L., 1996: Anhydrobiosis and cold tolerance in tardigrades. European Journal of Entomology, 93: 349-357.

Takeuchi, N., Kohshima, S., Yoshimura, Y., Seko, K., and Fujita, K., 2000: Characteristics of cryoconite holes on a Himalayan glacier Yala Glacier, Central Nepal. Bulletin of Glaciological Research, 17: 51-59.

Takeuchi, N., Kohshima, S. S., and Seko, K., 2001a: Structure, formation, and darkening process of albedo-reducing material (cryoconite) on a Himalayan glacier: a granular algal mat growing on the glacier. Arctic, Antarctic, and Alpine Research, 33: 115-122.

Takeuchi, N., Kohshima, S. S., Goto-Azuma, K., and Koerner, R. M., 2001b: Biological characteristics of dark colored material (cryoconite) on Canadian Arctic glaciers (Devon and Penny ice caps). Proceedings of the Memoris of National Institute of Polar Research, Special Issue, 54: 495-505.

Tranter, M., Fountain, A. G., Fritsen, C., Lyons, W. B., Priscu, J. C., Statham, P., and Welch, K. A. 2004. Extreme hydrochemical conditions in natural microcosms entombed within Antarctic ice. Hydrological Processes, 18: 379-387.

Treonis, A. M., Wall, D. H., and Virginia, R. A., 1999: Invertebrate biodiversity in Antarctic Dry Valley soils and sediments. Ecosystems, 2: 482-492.

Vincent, W. F., Gibson, J. A. E., Pienitz, R., Villeneuve, V., Borady, P. A., Hamilton, P. B., and Howard-Williams, C., 2000: Ice shelf microbial exosystems in the high Arctic and implications for life on snowball earth. Naturwissenschaften, 87: 137-141.

Virginia, R. A., and Wall, D. H., 1999: Soil animals in an extreme environment: how soils structure communities in the McMurdo Dry Valleys, Antarctica. BioScience, 49: 973-983.

Welch, K. A., Lyons, W. B., Graham, E., Neumann, K., Thomas, J. M., and Mikesell, D., 1996: Determination of major element chemistry in terrestrial waters from Antarctica by ion chromatography. Journal of Chromatography, 739: 257-263.

Wharton, R. A., Vinyard, W. C., Parker, B. C., Simmons, Jr., G. M., and Seaburg, K. G., 1981: Algae in cryoconite holes on Canada Glacier in Southern Victoria land, Antarctica. Phycologia, 20: 208211.

Wharton, Jr., R. A., McKay, C. P., Simmons, G. M., and Parker, B. C., 1985: Cryoconite holes on glaciers. BioScience, 8: 499-503.

Ms submitted November 2002 